Available online on 15.03.2020 at http://jddtonline.info
Open Access to Pharmaceutical and Medical Research
unrestricted non-commercial use, provided the original work is properly cited

open Access

Research Article

\title{
Total phenolic and flavonoids contents in the standardized polyherbal formulation "vayusadi guggulu"
}

\author{
1Vaishali Sharma, 2Monika Dhaka, ${ }^{2} J y o t i$ Dhama, Monika Sharma ${ }^{3}$, ${ }^{1}$ Md Rafiul Haque* \\ 1 Department of Pharmacognosy, HIMT College of Pharmacy, Knowledge park1, Gr. Noida (U.P), India \\ 2 Department of Pharmaceutics, HIMT College of Pharmacy, Knowledge park1, Gr. Noida (U.P), India \\ ${ }^{3}$ Department of pharmacology, HIMT College of Pharmacy, Knowledge park1, Gr. Noida (U.P), India
}

\begin{abstract}
Vayusadi guggulu vati (VGV), a polyherbal formulation is recommended for the management of diseases like obesity, arthritis, hyperlipidaemia and hyper cholesterol. Though Vayusadi guggulu vati is widely used for the treatment of obesity in Ayurvedic System of Indian Medicine, but till date, its quality standard study has not been carried out. In the present article, we evaluated the total phenolic and flavonoid contents in the standarised polyherbal VGV. The total phenolic content was determined by Folin Ciocalteu reagent (FC reagent) method. Aluminum chloride colorimetric method was used for total flavonoids contents determination. The VGV was standardized by physic-chemical parameters like total ash value, acid insoluble ash, loss on drying (LOD), PH, extractive value, phytochemical tests and thin layer chromatography (TLC). Determination of microbial load in different dilutions was also performed. Quality determination of vati (tablet) was also ev aluated with help of various tablet parameters. Microbial load study revealed the growth of microbes increases with increases the dilutions. The phenolic and flavonoid contents in VGV were $190.16 \pm 5.07 \mathrm{mg} / \mathrm{g}$ and $80.216 \pm 2.07 \mathrm{mg} / \mathrm{g}$ respectively. Physicochemical parameters such as total ash value $(9.73 \pm 1.45 \% \mathrm{~W} / \mathrm{W})$, acid insoluble ash $(1.85 \pm 0.40 \% \mathrm{~W} / \mathrm{W}), \mathrm{LOD}(4.77 \pm 0.45 \% \mathrm{~W} / \mathrm{W})$, PH $1 \%$ (4.6) water soluble extract $(64.69 \pm 3.42 \%$ $\mathrm{W} / \mathrm{W})$, alcohal soluble extract $(50.56 \pm 2.48 \% \mathrm{~W} / \mathrm{W})$ were assessed in preliminary physicochemical scanning. Thin layer chromatography (TLC) fingerprints study revealed that alcoholic and hexane extract of formulation showed 3 spots with different resolution in long wave UV 366 nm. TLC study revealed genuinely, quality and purity of formulation. Physico-chemical and microbial load result revealed that the formulation has a good quality. The inference from the present study may be used as reference standard in the further quality control researches.
\end{abstract}

Key words: Phenolic contents, flavonoid contents, microbial load, vayusadi guggulu vati

Article Info: Received 08 Jan 2020; Review Completed 18 Feb 2020; Accepted 26 Feb 2020; Available online 15 March 2020

Cite this article as:

Sharma V, Dhaka M, Dhama J, Haque M, Total phenolic and flavonoids contents in the standardized polyherbal formulation "vayusadi guggulu", Journal of Drug Delivery and Therapeutics. 2020; 10(2):97-101

http://dx.doi.org/10.22270/jddt.v10i2.3974

*Address for Correspondence:

Md Rafiul Haque, Department of Pharmacognosy, HIMT College of Pharmacy, Knowledge park1, Gr. Noida (U.P) India, Pin code - 201310

\section{INTRODUCTION}

Guggulu is an oleo gum resin obtained from the stem of Commiphora wightii (Hook ex. Stocks), belonging to family burseraceae. It is known to have analgesic, hyplipidaemic and anti- inflammatory action 1 . Guggulu is the principal ingredient of VGV formulations. It is also the main ingredient of several formulations such as Rasnadi guggulu, Vatari guggulu and yogaraja guggulu etc are traditionally used for musculoskeletal problems, body pain, osteoarthritis, obesity, sciatica and rheumatoid arthritis etc ${ }^{2}$. The preparation of VGV is based on traditional method mentioned in the Ayurvedic Pharmacopoeia of India. It is prepared from 10 ingredients (It is shown in table 1). Quality control studies of the herbal products are very important to justify its acceptability in the modern system of medicine. The change from batch to batch begins with the collection of the raw materials crude drugs themselves in the absence of any reference standard for identification and authentication. World Health Organization (WHO) has emphasized the need to standardization (ensure quality and purity) of herbal products using modern techniques and applying appropriate standards and parameters. Phenolic and flavonoids compounds are a class of antioxidant agents which act as free radical terminators. Some evidence suggests that the biological actions of these compounds are related to their antioxidant activity 3,4. Many published data reported that these compounds are very important for preventing the metabolic disorders 5, 6. Therefore, the present work is aimed to determine the total phenolic and flavonoids contents and also evaluated the physico- chemical parameters and microbial load in VGV. 
Table 1. Composition of VGV

\begin{tabular}{ccccc}
\hline S. no & Ingredients & Botanical name & Part used & Quantity \\
\hline 1 & Saunthi & Zingiber officinale & Rhizomes & 1 Part \\
2 & Marica & Piper nigrum & Flower & 1 Part \\
3 & Pippal & Piper longum & Flower & 1 Part \\
4 & Citraka & Plumbago zeylanica & Root & 1 Part \\
5 & Musta & Cyperus rotundus & Rhizomes & 1 Part \\
6 & HaritakI & Terminalia chebula & Plant & 1 Part \\
7 & Bibhitaka & Terminalia belerica & Plant & 1 Part \\
8 & Ëmalaki & Emblica officinalis & Plant & 1 Part \\
9 & Vidanga & Embelia ribes & Flower & 1 Part \\
10 & Guggulu & Commiphora wightii & Oleo gum Resin & 9 Part \\
\hline
\end{tabular}

\section{METARIALS AND METHODS}

\section{Procurement of VGV}

It was procured from local market at the month of January. The tablets were looking good and non-sticky. The colour, shape of vati (tablets) was analysed with naked eye.

\section{Determination of phenolic contents}

Sample Preparation: 1gm sample was dried \& powdered then reflux in $50 \mathrm{ml}$ of methanol for 2 hours. Collected the filtrate after filter it and evaporated the methanol and weight the residue \& reconstituted in methanol $10 \mathrm{mg} / \mathrm{ml}$.

Preparation of reagent: $10 \%$ phenolic reagent and sodium carbonate $(1 \mathrm{M})$ were prepared with distilled water

Methanol extract: Then taken $0.5 \mathrm{ml}$ of each methanolic extract and added in $5 \mathrm{ml} \mathrm{FC}$ reagent and $4 \mathrm{ml}$ of sodium carbonate then taken absorbance at $765 \mathrm{~nm}$ after $15 \mathrm{~min}$.

Preparation of standard solution: Standard (Gallic acid), $1 \mathrm{mg} / \mathrm{ml}$ solution in methanol was prepared. Then made dilution from 25 microgram to 300 microgram with methanol. Taken $0.5 \mathrm{ml}$ standard dilution and added into 5 $\mathrm{ml} \mathrm{FC}$ reagent \& $4 \mathrm{ml}$ of sodium carbonate then taken absorbance at $765 \mathrm{~nm}$ after $15 \mathrm{~min}$.

Blank solution: Taken $0.5 \mathrm{ml}$ methanol and $5 \mathrm{ml} \mathrm{FC}$ reagent \& $4 \mathrm{ml}$ sodium carbonate solution then taken absorbance at $765 \mathrm{~nm}$ after 15 minutes 7 . At first, prepared the curve and finded out regression equation and calculated the total phenolic content. The standard curve of gallic acid is shown in figure 1.

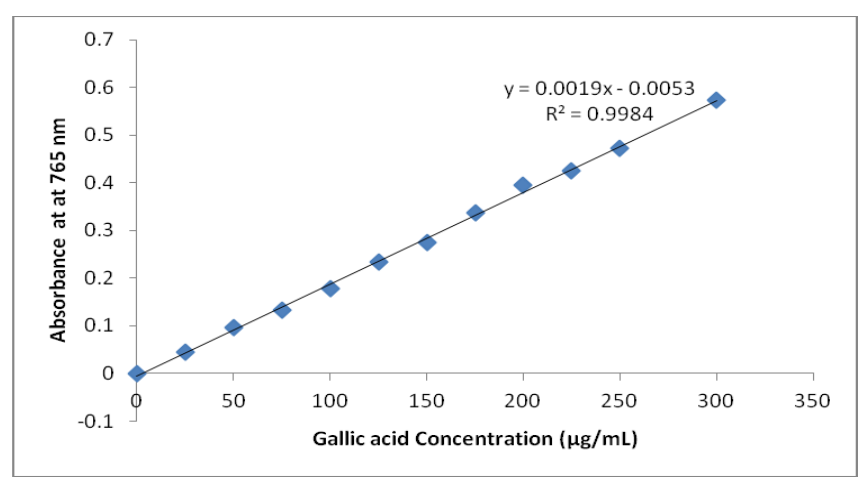

Figure 1. The standard curve of gallic acid

\section{Determination of flavonoid contents}

Sample preparation: Taken $0.5 \mathrm{ml}$ of extract from each solution, added $1.5 \mathrm{ml}$ of methanol, $0.1 \mathrm{ml}$ aluminium chloride and $0.1 \mathrm{ml}$ of sodium acetate then added $2.8 \mathrm{ml}$ of distilled water $\&$ kept for 30 minute after taking absorbance at $415 \mathrm{~nm}$.
Preparation of standard solution (quercetin): Taken $0.5 \mathrm{ml}$ of standard dilution, added $1.5 \mathrm{ml}$ methanol, $0.1 \mathrm{ml}$ aluminium chloride, $0.1 \mathrm{ml}$ sodium acetate then added $2.8 \mathrm{ml}$ distilled water and kept for 30 minute after taking absorbance at $415 \mathrm{~nm}$.

Preparation of blank solution: Taken $2 \mathrm{ml}$ of methanol, added $0.1 \mathrm{ml}$ aluminium chlorides and $0.1 \mathrm{ml}$ of sodium acetate, \& then added $2.8 \mathrm{ml}$ of distilled water. After taking absorbance of standard dilution as mentioned above, draw a calibration curve and finded out the regression equation and calculated the total flavonoid content ${ }^{7}$. The standard curve of quercetin is shown in figure 1.

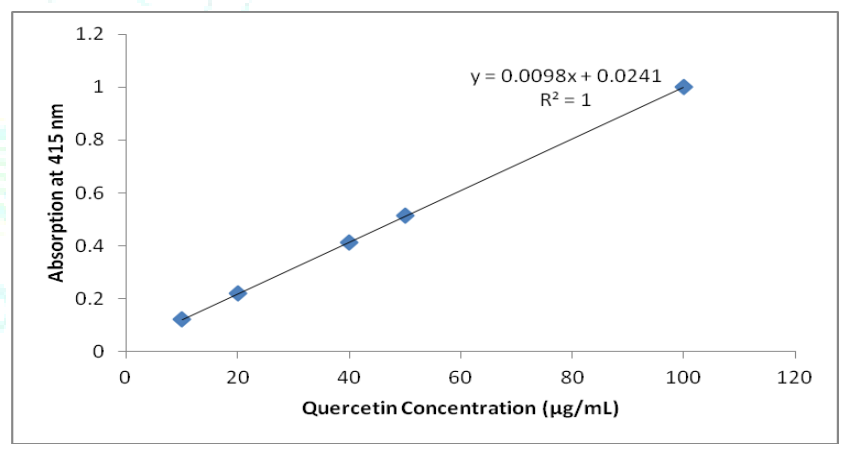

Figure 2. The standard curve of quercetin

\section{Physico- chemical properties}

\section{Determination of total ash}

Incinerated about 2 to $3 \mathrm{~g}$ of powdered drug accurately weighed in a tared platinum or silica dish at a temperature not exceeding $450^{\circ} \mathrm{c}$ until free from carbon, cooled and weighed and finally calculated the percentage of ash with reference to the air-dried drug8.

\section{Determination of acid-insoluble ash}

Boiled the ash obtained in for 5 minutes with $25 \mathrm{ml}$ of dilute hydrochloric acid; collected the insoluble matter in a Gooch crucible or on an ash less filter paper, washed with hot water and ignite to constant weight and lastly calculated the percentage of acid-insoluble ash with reference to the airdried drug8.

\section{Determination of alcohol-soluble extractive}

Macerated $5 \mathrm{~g}$ of the air-dried drug, coarsely powdered, with $100 \mathrm{ml}$ of alcohol of the specified strength in a closed flask for twenty-four hours, shaking frequently during six hours and allowing standing for eighteen hours. Filtered rapidly, taking precautions against loss of solvent, evaporate $25 \mathrm{ml}$ of the filtrate to dryness in a tared flat bottomed shallow dish, and dry at $105^{\circ}$, to constant weight and weighed and calculated the percentage of alcohol-soluble extractive with reference to the air-dried drug8. 


\section{Determination of water-soluble extractive}

Macerated $5 \mathrm{~g}$ of the air-dried drug, coarsely powdered, with $100 \mathrm{ml}$ of water of the specified strength in a closed flask for twenty-four hours, shaking frequently during six hours and allowing standing for eighteen hours. Filtered rapidly, taking precautions against loss of solvent, evaporate $25 \mathrm{ml}$ of the filtrate to dryness in a tared flat bottomed shallow dish, and dried at $105^{\circ}$, to constant weight and weighed and calculated the percentage of water-soluble extractive with reference to the air-dried drug8.

\section{LOD (Loss on drying)}

Procedure set forth here determined the amount of volatile matter (i.e., water drying off from the drug). For substances appearing to contain water as the only volatile constituent, the procedure given below, is appropriately used. Placed about $10 \mathrm{~g}$ of drug (without preliminary drying) after accurately weighing (accurately weighed to within $0.01 \mathrm{~g}$ ) it in a tared evaporating dish. For example, for unground or unpowered drug, prepare about $10 \mathrm{~g}$ of the sample by cutting shredding so that the parts are about $3 \mathrm{~mm}$ in thickness ${ }^{8}$.

\section{PH (1\%)}

Weighed $1 \mathrm{gm}$ sample and dissolved in $100 \mathrm{ml}$ distilled water to made $1 \%$ solution. [8]

\section{TLC}

Extracted $5 \mathrm{~g}$ of formulation powder with $75 \mathrm{ml} \mathrm{n}$-hexane under reflux on a water bath for $30 \mathrm{~min}$, filtered and concentrated to $10 \mathrm{ml}$ and carried out the thin-layer chromatography. Applied $10 \mathrm{ml}$ on TLC plate and developed the plate to a distance of $8 \mathrm{~cm}$ using toulen: acetone (9:1) as mobile phase. After development allowed the plate to dry in air and examine under ultraviolet light $(366 \mathrm{~nm})^{8}$.

\section{Phytochemical test for flavonoids}

Shinoda's test:

Taken about $2 \mathrm{ml}$ of ethanolic extract, three pieces of magnesium chips was then added to the filtrate followed by few drops of conc. HCl. A pink, orange, or red to purple colouration indicated the presence of flavonoids 9 .

\section{Alkaline reagent's test}

Taken about $2 \mathrm{ml}$ of ethanolic extract in a test tube then added few drops of $2 \% \mathrm{NaOH}$ solution, it produced dense yellow colour. After addition of few drops of dilute HCL, the solution disappeared the colour indicated the presence of flavonoids 9 .

\section{Determination of foaming index and swelling index}

Swelling index and foaming index of the formulation were measured as per method described in WHO guideline ${ }^{9}$.

\section{Determination of microbial counts explained as per WHO}

The microbial load was determined as per procedure of Dutt et al. 2020 7, 9. The medium was autoclaved at 151lbs per square inch pressure at $121^{\circ} \mathrm{C}$. The growth of microbial in petri-plates.

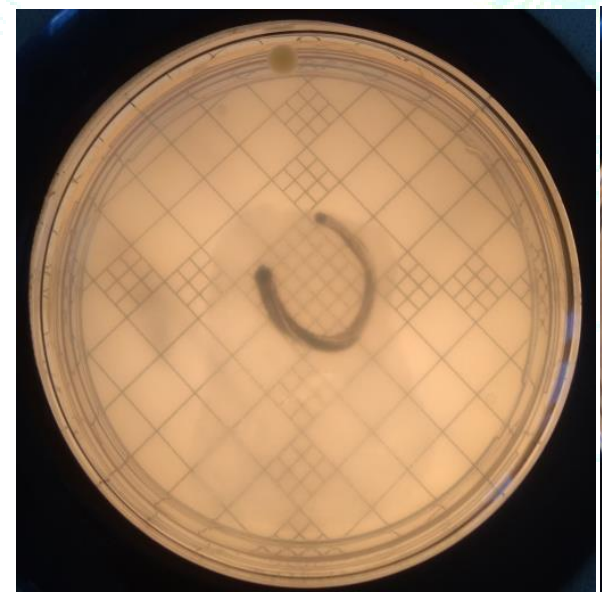

Control

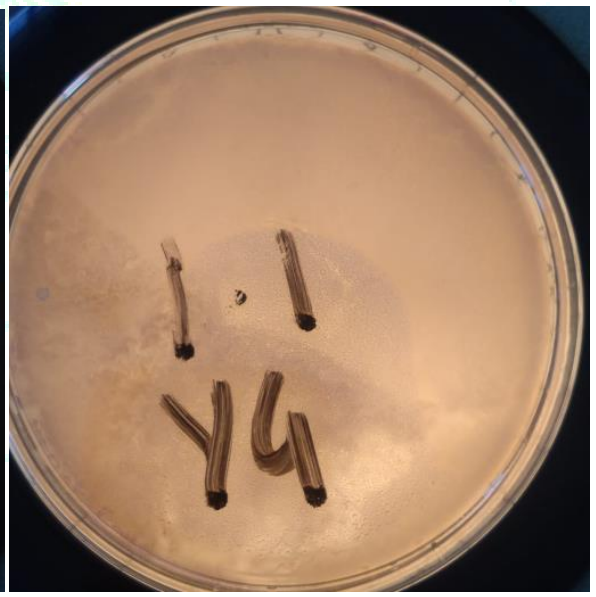

(1:1)

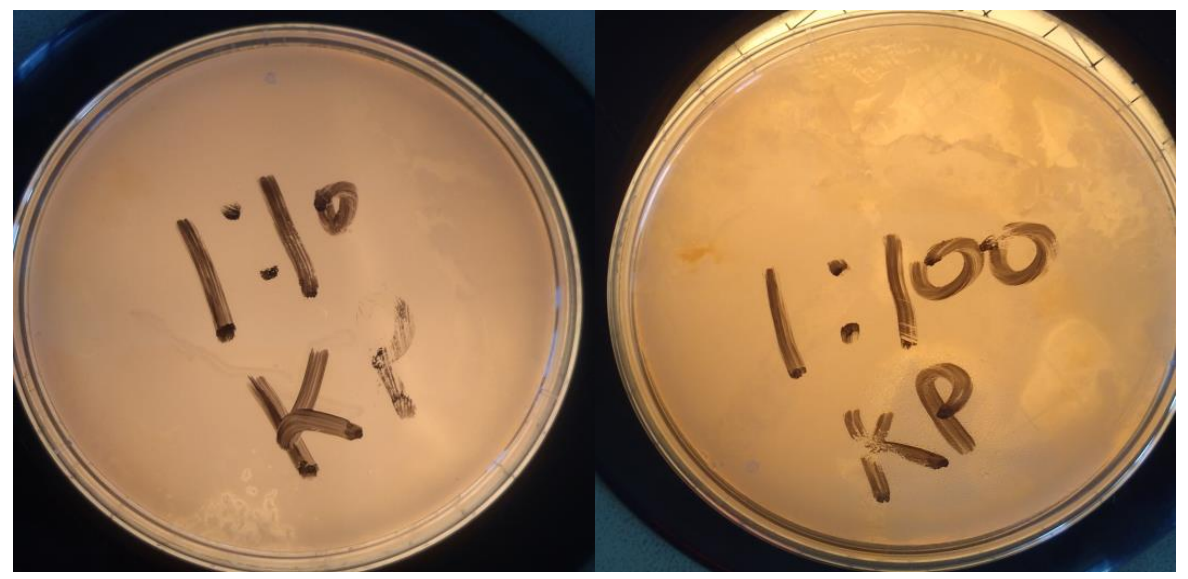

(1:10)

(1:100)

Figure 3. The growth of microbials in petri plates in different dilution. 


\section{Tablet parameters}

All tablet parameters such as diameter and thickness, weight variation, hardness, friability and disintegration were evaluated as per described in Indian Pharmacopoeias (IP) ${ }^{10}$.

\section{RESULTS}

\section{Organoleptic properties}

The organoleptic properties of VGV were shown in table 3.

Table 3. Result of description of VGV

\begin{tabular}{lll}
\hline S. No & Organoleptic parameters & Observation \\
\hline $\mathbf{1}$ & Colour & Black \\
$\mathbf{2}$ & Odour & Pleasant \\
$\mathbf{3}$ & Taste & Bitter \\
\hline
\end{tabular}

\section{Total phenolic and flavonoids contents}

The total phenolic and flavonoid content were found to be $190.16 \pm 5.07 \mathrm{mg} / \mathrm{g}$ and $80.216 \pm 2.07 \mathrm{mg} / \mathrm{g}$ dry extract respectively.

\section{Physico-chemical parameters}

Sample was found to be in prescribed range (pharmacopeial limits) for total ash $(9.73 \pm 1.45 \% \mathrm{~W} / \mathrm{W}$, acid insoluble ash $(1.85 \pm 0.40 \% \mathrm{~W} / \mathrm{W})$, alcohol extractive $(50.56 \pm 2.48 \%$ $\mathrm{W} / \mathrm{W})$, water extractive $(64.69 \pm 3.42 \% \mathrm{~W} / \mathrm{W})$, LOD $(4.77 \pm$ $0.45 \% \mathrm{~W} / \mathrm{W}$ ) and $\mathrm{PH}(4.6)$. It is shown in table 4 . The swelling index and foaming index of formulation were found to be zero. Thus, the sample did not contain saponin and mucilage. The extract for TLC was prepared in n- hexane and alcohol extract. A mixture of toluene: acetone (9:1) was taken as a mobile phase. N-hexane and alcoholic extract showed 4 spot at longer wavelength of $366 \mathrm{~nm}$ (properly separated, Figure 4). These standards exhibit a set of diagnostic, identity and authenticity of ayurvedic formulation. TLC profile generated in this study revising a standard tool for the authenticity of Ayurvedic extracts formulation and genuineness of the final product.

Table 4. Compared with Pharmacopeial standard

\begin{tabular}{cccc}
\hline S. No & Parameters & Observed Value & Pharmacopeia limit \\
\hline 1 & LOD $(\% \mathrm{~W} / \mathrm{W})$ & $4.77 \pm 0.45$ & NMT 15 percent \\
2 & Total Ash $(\% \mathrm{~W} / \mathrm{W})$ & $9.73 \pm 1.45$ & NMT 11 percent \\
3 & Acid insoluble ash $(\% \mathrm{~W} / \mathrm{W})$ & $1.85 \pm 0.40$ & NMT 3 percent \\
4 & Alcohol extractive $(\% \mathrm{~W} / \mathrm{W})$ & $50.56 \pm 2.48$ & NLT 21 percent \\
5 & Water extractive $(\% \mathrm{~W} / \mathrm{W})$ & $64.69 \pm 3.42$ & NLT 24 percent \\
6 & PH (1\%) & 4.6 & $4.57-4.69$ \\
7 & Shinoda's test & + & + \\
8 & Alkaline reagent's test & + & + \\
\hline
\end{tabular}

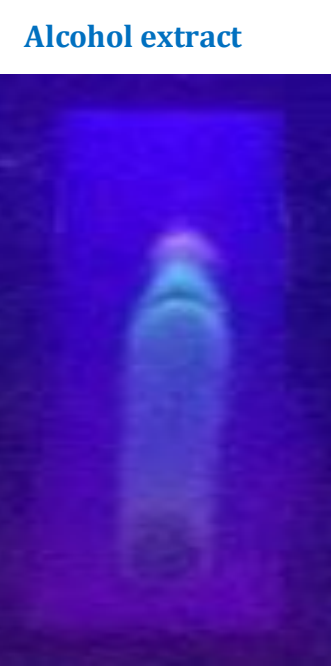

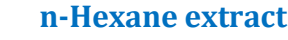

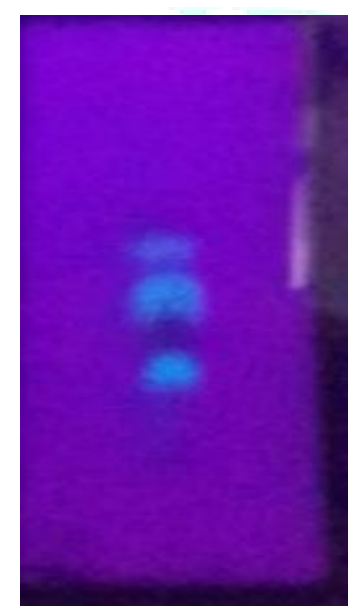

Toluene: Acetone (9:1) Toluene: Acetone (9:1)

Figure 4. TLC profile of VGV extract

\section{Microbial load determination}

VGV sample showed very less development microbial growth in 1:1(10 CFU), 1:10 (100 CFU) and 1:100 (220 CFU) dilutions which were under limits. From the results of microbial load reveal that the sample formulation has antimicrobial action, that is why it inhibits the growth of microbes.

\section{Results of tablet testing parameters}

The thickness of tablets was $0.5 \pm 0.02 \mathrm{~mm}$. Weight variation of sample was found to be -3.1 to $+5.1 \% \mathrm{~W} / \mathrm{W}$. The hardness and friability of sample were $2.6 \pm 0.5 \mathrm{Kg} / \mathrm{cm}^{2}$ and $0.562 \pm 0.05 \% \mathrm{~W} / \mathrm{W}$. The average disintegration time of sample was found to be $29 \pm 5.04 \mathrm{~min}$.[11] The results are shown in table 5.

Table 5. Result of tablet parameters

\begin{tabular}{lll}
\hline S. No & Parameters & Observed value \\
\hline 1 & Hardness & $2.6 \pm 0.5 \mathrm{Kg} / \mathrm{cm}^{2}$ \\
2 & Thickness & $0.5 \pm 0.02 \mathrm{~mm}$ \\
3 & Average wt & $539 \pm 5.07 \mathrm{mg}$ \\
4 & Weight variation & -3.1 to $+5.1 \% \mathrm{~W} / \mathrm{W}$ \\
5 & Friability & $0.562 \pm 0.05 \% \mathrm{~W} / \mathrm{W}$ \\
6 & Disintegration & $29 \pm 5.04 \mathrm{~min}$ \\
\hline
\end{tabular}

\section{DISCUSSION}

VGV is a traditional ayurvedic preparation prescribed for wide range of disorders. In this work an attempt has been made to determine total phenolic and flavonoid contents in standardized VGV. The standardization of VGV was done by different parameters such as ash value, $\mathrm{PH}$, extractive value, 
LOD, TLC fingerprinting, phytochemical tests and microbial load. The development of reliable quality protocols for ayurvedic formulations using modern techniques of analysis is extremely important.

The physical parameters such as ash value, extractive value, LOD and PH were found under pharmacopeial limits. The results from physico- chemical parameters indicated that the marketed preparation had good quality, strength and purity. Phenolic compounds are very important plant constituents because of their radical scavenging ability due to their hydroxyl groups 12, 6, 13. Phenolic compounds are a class of antioxidant agents which act as free radical terminators. Flavonoids are a group of polyphenolic compounds with known properties which include free radical scavenging, inhibition of hydrolytic and oxidative enzymes and antiinflammatory action. Some evidence suggests that the biological actions of these compounds are related to their antioxidant activity 3 , 4. Free radicals are involved in many disorders like neurodegenerative diseases, cancer and AIDS. Antioxidants through their scavenging power are useful for the management of those diseases. It has been recognized that phenolic and flavonoids show antioxidant activity and their effects on human nutrition and health are considerable ${ }^{14}$. The mechanisms of action of flavonoids are through scavenging or chelating process ${ }^{15}, 16$.TLC profile generated in this study revising a standard tool for the authenticity of Ayurvedic extracts formulation and genuineness of the final product. Many pathogens microbes such as Spirochete, Escherichia coli, Shigella, Salmonella, Enterobacter, Klebsiella, Citrobacter, Novoviruses, enteric hepatitis viruses, gastroenteritis viruses, enteroviruses and parasitic worms are present in water17, 18. In addition, different kinds of molds such as Aspergillus spp. Penicillium spp. are also present in water that are usually allergic and toxigenic ${ }^{19}$. These fungi are not only accountable for the adverse effects on health but also cause taste and odour problems in drinking water ${ }^{20}$. The thickness of tablets was performed on 20 tablets from each formulation. Digital Vernier caliper was used for the study, which permits accurate measurements and provides information of the variation between tablets. Weight variation was carried out to ensure that, each of tablets contains the proper amount of drug. The test was carried out by weighing the 20 tablets individually using analytical balance, then calculating the average weight, and comparing the individual tablet weights to the average 10 . The resistance of tablets to capping, abrasion or breakage under conditions of storage, transportation and handling before usage depends on its hardness. Tablet hardness is defined as the load required crushing or fracture a tablet placed on its edge. Sometimes it is also termed as tablet crushing strength. The hardness test was performed using Monsant type (Make: Singhla) hardness tester. The instrument measures the force required to break the tablet when the force generated by anvils to the tablet The tablet was placed between two anvils; force applied to the anvils, and the crushing strength that just causes the tablet to break was recorded. The crushing strength test was performed on 20 tablets from each formulation.

\section{CONCLUSIONS}

The result of the present study showed that the extract of VGV has remarkable phenolic compounds and also contain flavonoid compounds. Due to presence of these compounds, it may show the greatest antioxidant activity and its related activities. VGV also showed good quality, purity and less development of microbial contamination. The outcomes from various physico-chemicals and testing of tablet parameters may be differentiating qualities from many other vati formulations of guggulu.

\section{ACKNOWLEDGEMENT}

Authors are thankful to Department of Pharmacognosy, HIMT College of Pharmacy for providing all necessary facilities for this work.

\section{REFERENCES}

1. Shalini, Prajapati PK, Harisha CR, Pandya DH, Quality control parameters of Vatari guggulu- an ayurvedic formulation. IJAPR. 2016; 4:6 13-18.

2. Das NP, Pereira TA. Effects of flavonoids on thermal autooxidation of Palm oil: structure- activity relationship. J. American Oil Chemists Society. 1990; 67:255- 258.

3. Chu Y, Flavonoid content of several vegetables and their antioxidant activity. J. Sci. Food and Agric. 2000; 80:561 - 566.

4. Halliwell B, Free radicals, antioxidants, and human disease: curiosity, cause, or consequence. Lancet. 1994; 344:721- 724.

5. Haque MR, Ansari SH, Najmi AK, Ahmad MA. Monoterpene phenolic compound thymol prevents high fat diet induced obesity in murine model. Toxicol. Mech. Methods. 2014; 2:116123.

6. Haque MR, Ansari HS, Anti-obesity effect of arq zeera and its main components thymol and cuminaldehyde in high fat diet induced obese rats Drug res. 2018; 11:637-647.

7. Dutt V, Srivastav S, Mittal S, Haque MR, Determination of microbial load, total Phenolic and flavonoids contents in polyherbal formulation "yograj guggulu vati”, J. Drug Deliv. Ther. 2020; 10:1-5.

8. The Ayurvedic Pharmacopoeia of India (API), Part - II (Formulations) Volume - II, First Edition Government of India, ministry of Health And Family Welfare Department Of Ayurveda, Yoga \& Naturopathy, Unani, Siddha And Homoeopathy, New Delhi Anonymous, 2008.

9. Trease GE, Evans WC, Pharmacognosy. 15th ed. Saunders Publishers, London; 2000. 42-44

10. Anonymous, 1998. Quality Control Methods for Medicinal Plant Materials. World Health Organization. Geneva.

11. Anonymous, 2014. Indian Pharmacopoeia (IP) seventh edition, the Indian Pharmacopoeia Commission (IPC) the Government of India, Ministry of Health \& Family Welfare.

12. Chang C, Yang M, Wen $H$, Chern J. Estimation of total flavonoid content in propolis by two complementary colorimetric methods. J. Food Drug Analaysis, 2002; 10:178-182.

13. Haque MR, Ansari SH. Immunostimulatory effect of standardised alcoholic extract of green tea (Camellia sinensis L.) against cyclophosphamide-induced immunosuppression in murine model. Int. J. Green Pharm. 2014; 8:52-7.

14. Haque MR, Ansari SH, Rashikh A. Coffea arabica seed extract stimulate the cellular immune function and cyclophosphamideinduced immunosuppression in mice. Iranian J. Pharm. Res. 2013; 12:101-108.

15. Kessler M, Ubeaud G, Jung L, Anti- and pro-oxidant activity of rutin and quercetin derivatives. J. Pharm. and Pharmacol. 2003; 55:131- 142 .

16. Cook NC, Samman S. Flavonoids- chemistry, metabolism, cardioprotective effects, and dietary sources. Nutr. Biochem. 1996; 7: 66- 76.

17. Bharti AR, Nally JE, Ricaldi JN, Matthias MA, Diaz MM, Lovett MA, Levett PN, Gilman RH, Willig MR, Gotuzzo E, Vinetz JM. Leptospirosis a zoonotic disease of global importance. Lancet. Infect. Dis. 2003; 3:757-571

18. Bosch, A., Human viruses in water 2007.Elsevier Science, Amsterdam.306

19. Hageskal G, Gaustad P, Heier BT, Skaar I. Occurrence of molds in drinking water. J. App. Microbiol, 2006; 102:774-780.

20. Haque MR, Ansari SH, Naquvi KJ and Najmi AK. Quality Assessment of a traditional Unani Formulation Arq Zeera. Journal of Pharmacy Research 2012; 5(2):778-782. 